\title{
Optimization of Alginate-Based Encapsulation Utilization For Viability and Stability of The Mesenchymal Stem Cell
}

\author{
Rilianawati $\mathbf{R}^{1}$, Ago $\mathbf{H}^{2}$, Subintoro ${ }^{1}$, Elrade $\mathbf{R}^{1}$, Kurnia $\mathbf{A}^{1}$
}

${ }^{1}$ Center of Pharmaceutical and Medical Technology,Agency for the Assessment and Application of Technology, Jakarta, Indonesia

${ }^{2}$ Dermatovenereology department, Christian University of Indonesia

\begin{abstract}
In the past few decades, attention and research in the field of stem cell are progressing very rapidly. Hospitals in Indonesia have been using stem cells as an alternative to cure some illnesses like diabetes, heart disease, fractures and joints, dental implants, etc. Currently, adult stem cells can be obtained not only from the spinal cord and peripheral vessels, but also from fat tissues of the human body, where it can be isolated as adherent stem cells (mesenchymal stem cells). Consideration of fat tissue as the source of mesenchymal stem cells (MSCs) for autologous tissue engineering is because they are readily available in abundant quantities through minimal invasive procedures, as well as easily cultured and propagated. It is possible to proliferate and differentiate into the desired direction of the network. Stem cell growth requires conditions to grow such as requiring optimum growing conditions such as an environmental temperature of $37^{\circ} \mathrm{C}$ and a concentration of $5 \% \mathrm{CO}_{2}$. Maintenance of MSCs also requires a subculture process, i.e. the process of moving MSCs from a full culture medium to new media; continuous subculture process can cause changes in MSCs. The viability of stem cells may be disrupted by micro-conditions in wounds such as hypoxia, oxidative stress, and inflammation. Therefore, the purpose of this research was to investigate whether alginate-based encapsulation can increase and maintenance stem cell growth at different temperature by using some concentration of alginate and $\mathrm{CaCl}_{2}$ as the formula. Results shown that alginat with low concentration and $\mathrm{CaCl}_{2} 100 \mathrm{mM}$ is suitable for MSCs growth (as in MTT result shown) at $25^{\circ} \mathrm{C}$ temperature. This can be due to the MSCs encapsulated can adapt and grow within the alginate microcapsule with low concentration. In addition, the media may also easier to get into the microcapsule alginate.
\end{abstract}

Keywords: Mesenchymal stem cells; Fat tissue; Adherent stem cells; Alginate

\section{Introduction}

Mesenchymal stem cells (MSCs) are a prospective object for the use in cell therapy and intensely studied by many research groups. MSCs are characterized primarily by expression of surface markers and differentiation potential. MSCs express a series of specific markers (CD44, CD90, CD105, CD13, etc.) and should differentiate into cells of mesodermal origin such as adipocytes, osteoblasts and chondroicytes. Due to the easy accessible anatomical location and the abundant existence of subcutaneous adipose tissue, ADSC hold the advantage of a simple and above all less invasive harvesting technique. Consideration of fat tissue as the source of mesenchymal stem cells (MSCs) for autologous tissue engineering is because they are readily available in abundant quantities through minimal invasive procedures, as well as easily cultured and propagated. It is possible to proliferate and differentiate into the desired direction of the network. Stem cell growth requires conditions to grow such as requiring optimum growing conditions such as an environmental temperature of $37^{\circ} \mathrm{C}$ and a concentration of $5 \% \mathrm{CO}_{2}$. Maintenance of MSCs also requires a subculture process, i.e. the process of moving MSCs from a full culture medium to new media; continuous subculture process can cause changes in MSCs. The viability of stem cells may be disrupted by micro-conditions in wounds such as hypoxia, oxidative stress, and inflammation.

Alginate is an anionic polymer compound which can be obtained from brown algae and Pseudomonas and Azotobacter microbes. Alginate includes a group of non-branched and non-recurrent exopolisakarida composed of two monomers namely $\beta$-D-mannuronic acid and $\alpha$-L-guluronic acid. Alginate will interact with divalent cations, such as $\mathrm{Ca}^{2+}$, and form a 3D structure. The ability of alginate to form 3D structure and its low toxicity characteristics and high biocompatibility make alginate widely used for encapsulation process.
Cell encapsulation is a method of cell capture in a polymeric semipermeable membrane, generally biocompatible encapsulation materials such as chitosan, hyaluronic acid, and alginate. Encapsulation is generally done to protect the cell. Encryption of embryonic stem cells with alginate is reported to maintain viability of stem cells for 110 days without undergoing differentiation and without requiring subculture maintenance [1]. Encapsulation of MSCs with alginate- $\mathrm{CaCl}_{2}$ is known to maintain viability in hypothermic conditions $\left(<37^{\circ} \mathrm{C}\right)$ and without specific gas concentrations [2]. Encapsulation can also protect stem cells from frictional forces, microenvironment, and immune responses [3]. The method of cell encapsulation involves 2 main stages: dispersion of the solution containing the cell to be small and followed by gelation or membrane formation on the surface of the dispersed solution, for example extrusion method of droplets. Alginate solution will be extruded through nozzle or needle so as to produce droplets of a certain size. The droplet size setting can be done by adjusting the extrusion speed and the size of the nozzle [4-9]. Therefore, the purpose of this research was to investigate whether alginate-based encapsulation can

*Corresponding author: Rilianawati R, Center of Pharmaceutical and Medical Technology, Agency for the Assessment and Application of Technology, Jakarta, Indonesia, Tel: 62-895353263161; Fax: 62-21-7560707; E-mail: liliabbas@gmail.com; rilianawati@bppt.go.id

Received December 18, 2017; Accepted February 20, 2018; Published February 26, 2018

Citation: Rilianawati R, Ago H, Subintoro, Elrade R, Kurnia A (2018) Optimization of Alginate-Based Encapsulation Utilization For Viability and Stability of The Mesenchymal Stem Cell. J Stem Cell Res Ther 8: 412. doi: 10.4172/21577633.1000412

Copyright: (c) 2018 Rilianawati R, et al. This is an open-access article distributed under the terms of the Creative Commons Attribution License, which permits unrestricted use, distribution, and reproduction in any medium, provided the original author and source are credited. 
increase and maintenance stem cell viability at diferent temperature by using some concentration of alginate and $\mathrm{CaCl}_{2}$ as formula.

\section{Material and Methods}

\section{Mesenchymal Stem Cell Culture (MSCs)}

MSCs were cultured on $a$-MEM media given the addition of Platelet Rich Plasma (PRP), Penicillin / Streptomycin, and Heparin. Media replacement grows every 3 days. MSCs subculture is growth well when the MSCs are confluent $\pm 80 \%$.

\section{MSCs encapsulation optimization}

Optimization of $\mathrm{CaCl}_{2}$ concentrations: Alginate solution (Sigma Aldrich, medium viscosity) was prepared at concentrations of $1.25 \%$ (w $/ \mathrm{v})$. The $1 \times 10^{6}$ mesenchymal stem cells are mixed in $1 \mathrm{ml}$ of alginate solution. The solution was then dropped in the form of droplets by extrusion method using a $31 \mathrm{G}$ syringe at $200 \mathrm{mM} \mathrm{CaCl}_{2}$ solution with contact time of $\pm 30 \mathrm{~min}$. The formed microcapsules were then washed using $0.9 \% \mathrm{NaCl} 3$ times and stored in culture medium. The concentration of $\mathrm{CaCl}_{2}$ to be used in the next step was selected based on the results of the MSCs encapsulated viability test on days $0,1,7$, $14,21,28$.

Alginate encapsulation optimization: Alginate solution was prepared at concentrations of $1 \%$ in Aqua Sterile. The $1 \times 10^{6}$ mesenchyme stem cells are mixed in $1 \mathrm{ml}$ of alginate solution. Alginate solution at various concentrations was then dropped in the form of droplets by extrusion method using $31 \mathrm{G}$ syringe at $\mathrm{CaCl}_{2}$ solution with concentration based on $\mathrm{CaCl}_{2}$ concentration optimization result with contact time $\pm 30 \mathrm{~min}$. The formed microcapsules were then washed using $0.9 \% \mathrm{NaCl}$ and stored in culture medium. These microcapsules are incubated at different temperatures at $4^{\circ} \mathrm{C}$ (refrigeratore) and $37^{\circ} \mathrm{C}$ (incubator) for 0-28 days. The optimum concentration of alginate is selected by testing the viability and stability of MSCs encapsulated.

\section{Analysis of stem cell encapsulation}

De-capsulation of alginate-based microcapsules: Microcapsules were observed morphologically through a microscope every day until day 28 . On the $1^{\text {st }}, 7^{\text {th }}, 14^{\text {th }}, 21^{\text {st }}$ and $28^{\text {th }}$ days, a viability test and stability of mesenchymal stem cells in microcapsules were performed. The microcapsules were decapitated using $500 \mathrm{mM}$ EDTA solution/10 $\mathrm{mM}$ HEPES in $500 \mathrm{~mL}$ PBS. Decapsulation incubate in 15 minutes in a waterbath shaker with a temperature of $37^{\circ} \mathrm{C}$. The solution mixture was then centrifuged for 5 minutes at a rate of $1200 \mathrm{rpm}$ and obtained a cell pellet which was then diluted with $2 \mathrm{ml}$ growing medium.

MTT (3- (4,5-Dimethylthiazol-2-yl) -2,5-Diphenyltetrazolium Bromide) assay: The viability of mesenchymal stem cells during the process of encapsulation and incubation of cells can remain proliferate using MTT assay. Transfer of decapsulated cells into the wells is $100 \mu \mathrm{L}$. Added reagent of MTT $(0.5 \mathrm{mg} / \mathrm{mL})$ as much as $100 \mu \mathrm{L}$ then incubation in incubator $37^{\circ} \mathrm{C}, 5 \% \mathrm{CO}_{2}$ for 4 hours. After that add $10 \%$ SDS into the well and incubated for 24 hours at room temperature. Absorbance was measured using an ELISA reader at a wavelength of $595 \mathrm{~nm}$.

Live dead assay (LDA): Live Dead Assay were analyze using Propidium Iodine (PI) as a marker of dead cells and Calcein Am as a living cell marker, with concentrations of PI $=10 \mu \mathrm{M}$ and Calcein $2 \mu \mathrm{M}$.

Stability analysis: The cell stability assay was used to see whether differentiation of mesenchymal stem cells during encapsulation was performed. Differentiation into adipocyte cells was tested using Oil red-O staining, whereas differentiation testing became chondrocytes and osteoblasts were each tested using alcian blue and alizarin red staining.

\section{Result and Discussion}

\section{Alginate 2\% with $\mathrm{CaCl} 2100 \mathrm{mM}$ (Figure 1 and 1a)}

MTT (3- (4,5-Dimethylthiazol-2-yl) -2,5-Diphenyltetrazolium Bromide) Assay: At $37^{\circ} \mathrm{C}$ temperature indicates that the growth of

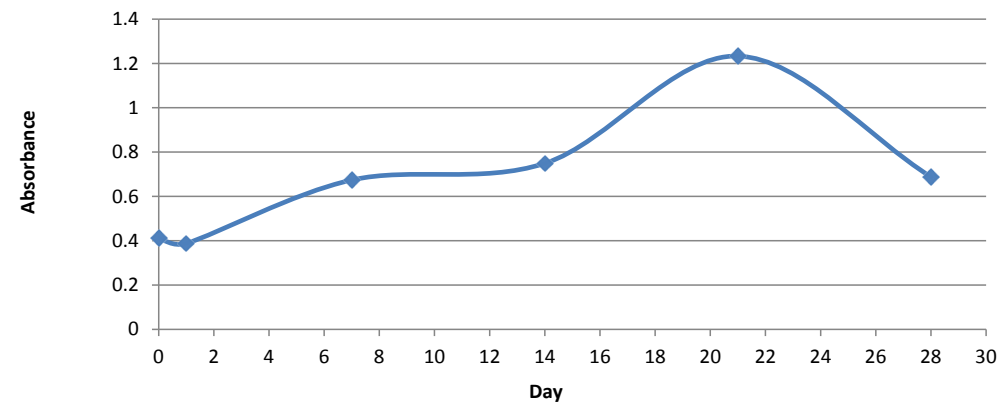

Figure 1: Absorbance value based on MTT assay of Alginate $2 \%$ with $\mathrm{CaCl}_{2} 100 \mathrm{mM}$ at $37^{\circ} \mathrm{C}$

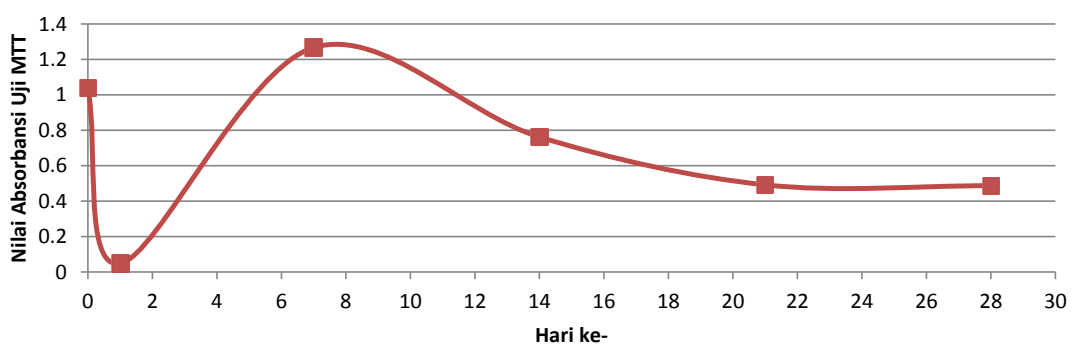

Figure 1a: Absorbance value based on MTT assay of Alginate $2 \%$ with $\mathrm{CaCl}_{2} 100 \mathrm{mM}$ at $25^{\circ} \mathrm{C}$. 
Citation: Rilianawati R, Ago H, Subintoro, Elrade R, Kurnia A (2018) Optimization of Alginate-Based Encapsulation Utilization For Viability and Stability of The Mesenchymal Stem Cell. J Stem Cell Res Ther 8: 412. doi: 10.4172/2157-7633.1000412

Page 3 of 14

MSCs in alginate microcapsules begins to increase on the $7^{\text {th }}$ day until the $21^{\text {st }}$ day. While after the $21^{\text {st }}$ day, the growth of MSCs began to look declining. This can be due to the need for time for the MSCs to adapt and grow within the alginate microcapsule. In addition, the media may also need time to get into the microcapsule alginate. While MSCs growth in $37^{\circ} \mathrm{C}$ temperature can grow well due to conditions in temperature $37^{\circ} \mathrm{C}$ is the optimum temperature for stem cells to grow. At $25^{\circ} \mathrm{C}$ temperature indicates that the growth of MSCs in alginate microcapsules begins to increase on the 7th day. While after the 7th day, the growth of MSCs began to look declining continously. This can be due to the need for time for the MSCs to adapt and grow within the alginate microcapsule.

Live dead assay (LDA): Viability of MSCs after alginate encapsulated MSCs for day-0, day-1, day-7, day-14, day-21, and day-28 using Live-dead cell assay (Alginate $2 \%$ with $\mathrm{CaCl}_{2} 100 \mathrm{mM}$ ) (Table 1 ).

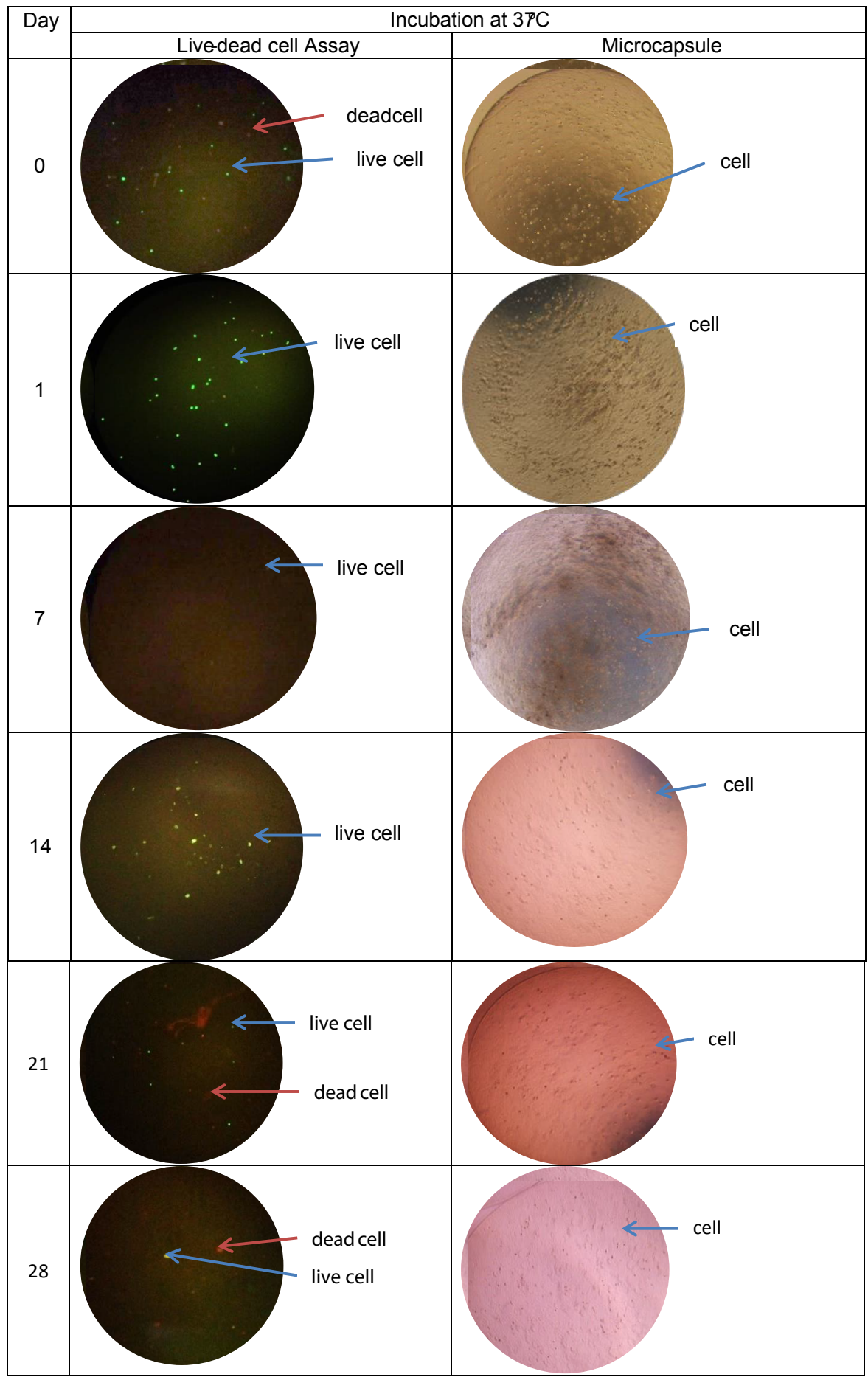

Table 1: Viability of MSCs after alginate encapsulated MSCs for day-0, day-1, day-7, day-14, day-21, and day-28 using Live-dead cell assay (Alginate $2 \%$ with CaCl $100 \mathrm{mM})$. 
Citation: Rilianawati R, Ago H, Subintoro, Elrade R, Kurnia A (2018) Optimization of Alginate-Based Encapsulation Utilization For Viability and Stability of The Mesenchymal Stem Cell. J Stem Cell Res Ther 8: 412. doi: 10.4172/2157-7633.1000412

Stability assay (Table 2): From the LDA analysis shows that MSCs is still alive from day- 0 to day- 28 in the alginate microcapsule but seen the amount of MSCs decreased from day-0 to day-28. And from stability analysis shows that there is no adipose, chondrocytes and osteoblasts differentiation.
Alginate $1.75 \%$ with $\mathrm{CaCl}_{2} 100 \mathrm{mM}$ (Figure 2 and $2 \mathrm{a}$ ): At $37^{\circ} \mathrm{C}$ temperature showed MSCs growth increased after day 1 to day 7. After day 7 , growth declined significantly and increased again after day 14 . After the 21st day, the MSCs growth declined again. From Graph shows that the growth of MSCs in the microcapsule of alginate $1.75 \%$ with

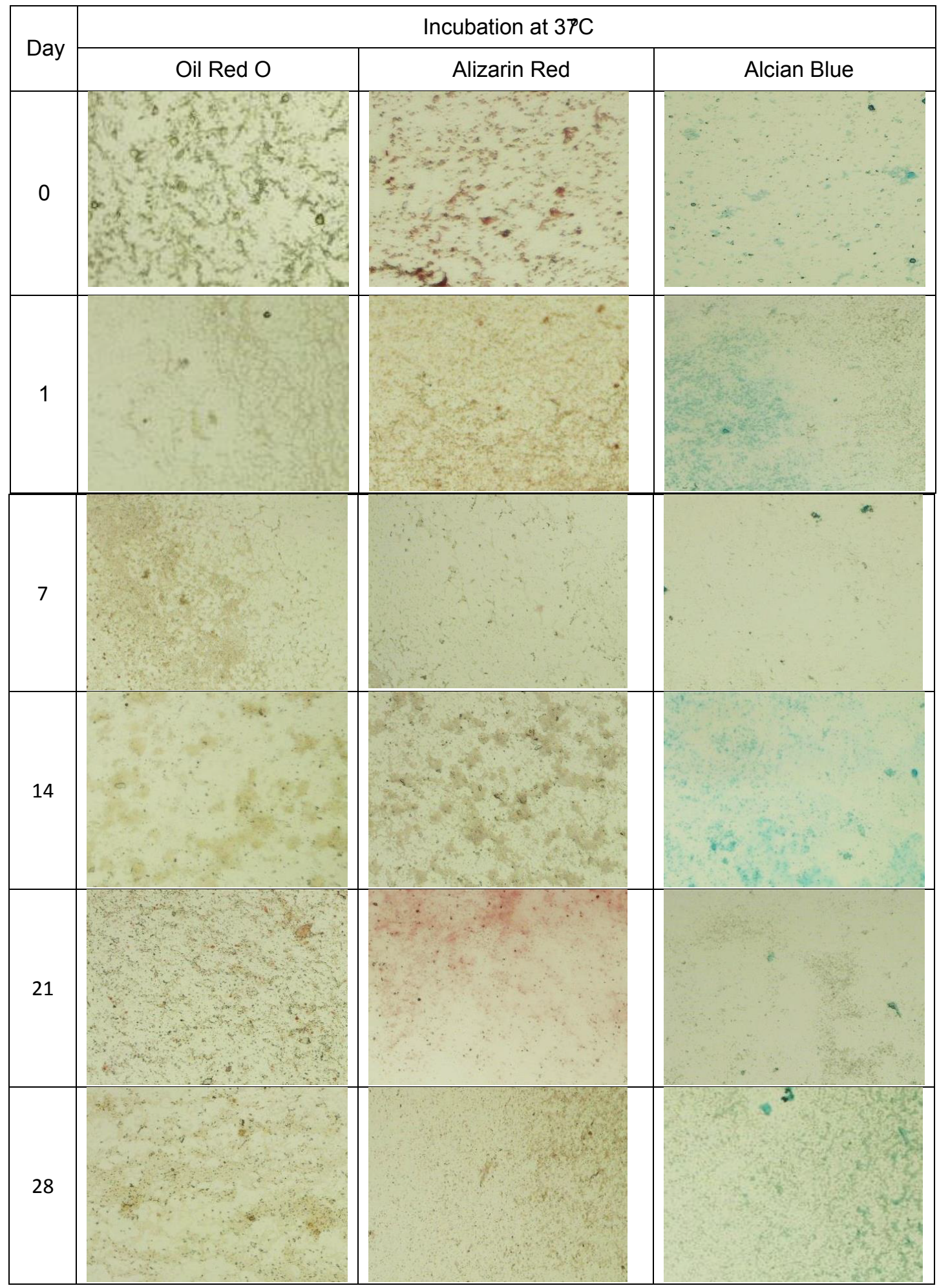

Table 2: Stability of MSCs (Alginate $2 \%$ with $\mathrm{CaCl}_{2} 100 \mathrm{mM}$ ) using Oil Red O, Alizarin Red and Alcian Blue staining 


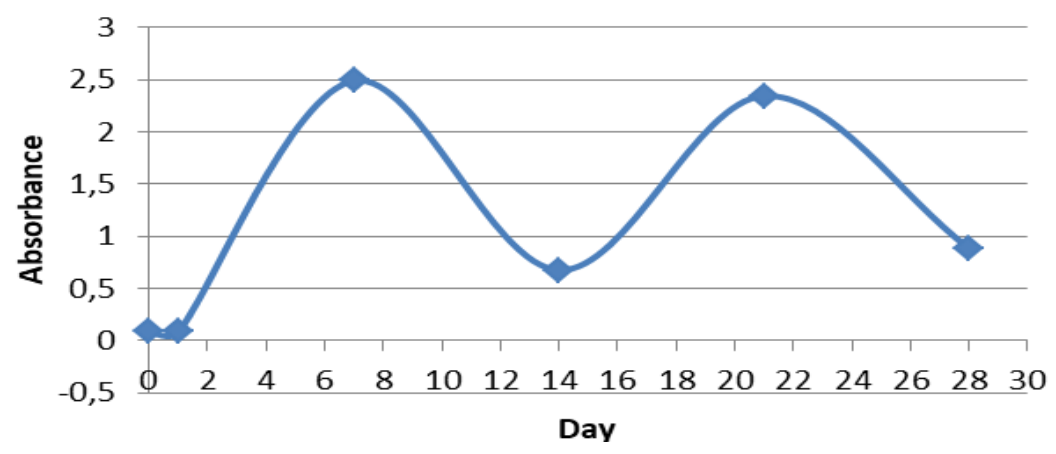

Figure 2: Absorbance value based on MTT assay of Alginate $1.75 \%$ with $\mathrm{CaCl}_{2} 100 \mathrm{mM}$ at $37^{\circ} \mathrm{C}$

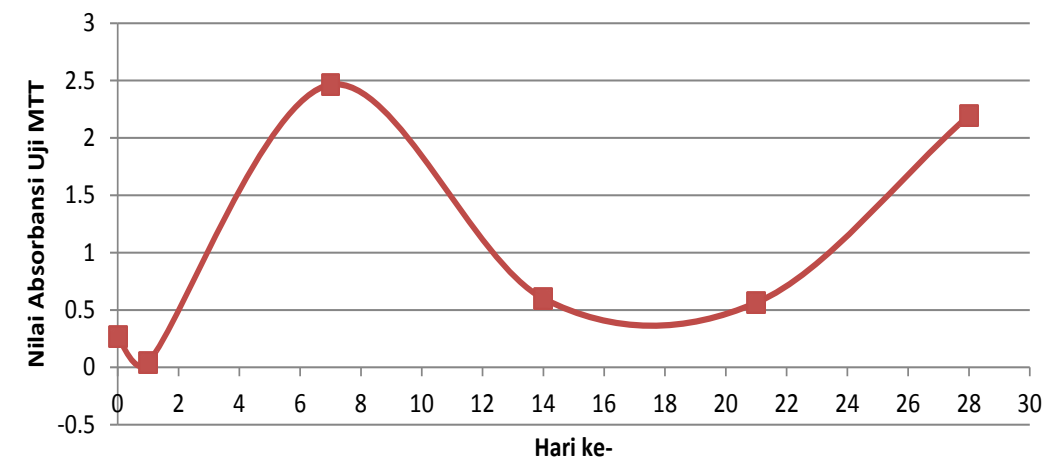

Figure 2a: Absorbance value based on MTT assay of Alginate $1.75 \%$ with $\mathrm{CaCl}_{2} 100 \mathrm{mM}$ at $25^{\circ} \mathrm{C}$.

$\mathrm{CaCl}_{2} 100 \mathrm{mM}$ is unstable and irregular. At $25^{\circ} \mathrm{C}$ temperature showed MSCs growth increased after day 1 to day 7 . After day 7, growth declined significantly and increased again after day 21 . After the 21 st day, the MSCs growth increased again. From Graph shows that the growth of MSCs in the microcapsule of alginate $1.75 \%$ with $\mathrm{CaCl}_{2}$ $100 \mathrm{mM}$ is unstable and irregular.

\section{Live Dead Assay (LDA) (Table 3)}

Stability assay: Stability of MSCs (Alginate $1,75 \%$ with $\mathrm{CaCl}_{2} 100$ $\mathrm{mM}$ ) using Oil Red O, Alizarin Red and Alcian blue staining (Table 4).

\section{Alginate $1.5 \%$ with $\mathrm{CaCl}_{2} 100 \mathrm{mM}$ (Figure 3 and 3a)}

At $37^{\circ} \mathrm{C}$ temperature, MSCs growth increased from 0 to equal to day 14. After day 14, the growth of MSCs decreases and increases again after the 21 st day until the 28 th day. At $25^{\circ} \mathrm{C}$ temperature, MSCs growth increased from day 1 to day 28 . While MSCs growth at $25^{\circ} \mathrm{C}$ temperature can grow well same at conditions at $37^{\circ} \mathrm{C}$ temperature is the optimum temperature for stem cells to grow. This Formula seems that suitable for MSCs-encapsulated grow.

Live dead assay (LDA): Viability of MSCs after alginate encapsulated MSCs for day-0, day-1, day-7, day-14, day-21, and day-28 using Livedead cell assay (Alginate $1.5 \%$ with $\mathrm{CaCl}_{2} 100 \mathrm{mM}$ ) (Table 5).

Stability assay: Stability of MSCs (Alginat $1.5 \%$ with $\mathrm{CaCl}_{2} 100 \mathrm{mM}$ ) using Oil Red O, Alizarin Red and Alcian blue staining (Table 6). From the stability analysis showed that there was no differentiation on MSC encapsulated for 28 days and still seen fibroblasts.

\section{Alginate $1.25 \%$ with $\mathrm{CaCl}_{2} 100 \mathrm{mM}$}

MTT (3- (4,5-Dimethylthiazol-2-yl) -2,5-Diphenyltetrazolium Bromide) Assay (Figure 4): At alginat $1.25 \%$ with $\mathrm{CaCl}_{2} 100 \mathrm{mM}$, at $37^{\circ} \mathrm{C}$, MSCs growth increased from day- 0 to day-28. This shows that alginate $1.25 \%$ with $\mathrm{CaCl}_{2} 100 \mathrm{mM}$ is good for MSCs growth (Figure $4 \mathrm{a}$ ). At alginat $1.25 \%$ with $\mathrm{CaCl}_{2} 100 \mathrm{mM}$, at $25^{\circ} \mathrm{C}$, MSCs growth increased from day- 0 to day-28. This shows that alginat $1.25 \%$ with $\mathrm{CaCl}_{2} 100 \mathrm{mM}$ is good for MSCs growth.

Live Dead Assay (LDA): Viability of MSCs after alginate encapsulated MSCs for day-0, day-1, day-7, day-14, day-21, and day-28 using Live-dead cell assay (Alginate $1.25 \%$ with $\mathrm{CaCl}_{2} 100 \mathrm{mM}$ ) (Table 7).

Stability assay: Stability of MSCs (Alginate $1.25 \%$ with $\mathrm{CaCl}_{2} 100 \mathrm{mM}$ ) using Oil Red O, Alizarin Red and Alcian blue staining (Table 8).

\section{Alginate $1 \%$ with $\mathrm{CaCl}_{2} 100 \mathrm{mM}$}

MTT (3- (4,5-Dimethylthiazol-2-yl) -2,5-Diphenyltetrazolium Bromide) Assay (Figure 5): At $37^{\circ} \mathrm{C}$ temperature MSCs growth has increased from day 0 to day 1 . Furthermore, MSC growth decreased on day 7 and increased again until $21^{\text {st }}$ day. On day 28 , the growth of MSC shows a drastic decline. (Figure 5a) At alginat $1 \%$ with $\mathrm{CaCl}_{2}$ $100 \mathrm{mM}$, at $25^{\circ} \mathrm{C}$, MSCs growth increased from day 0 to day 28 . This shows that alginat $1 \%$ with $\mathrm{CaCl}_{2} 100 \mathrm{mM}$ is good for MSCs growth. This can be due to the MSCs encapsulated can adapt and grow within the alginate microcapsule. In addition, the media may also to get into the microcapsule alginate. 


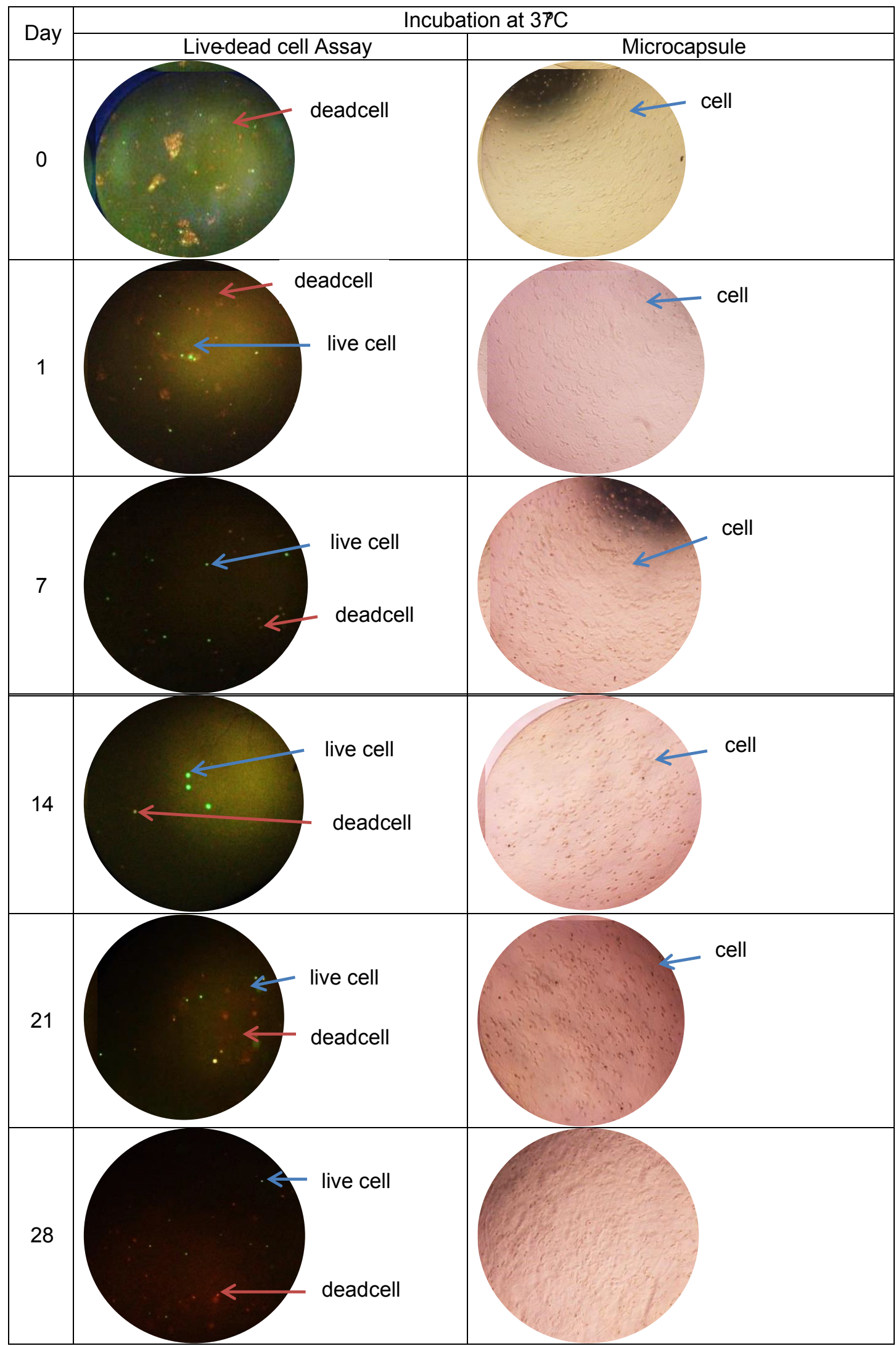

Table 3: Viability of MSCs after alginate encapsulated MSCs for day-0, day-1, day-7, day-14, day-21, and day-28 using Live-dead cell assay (Alginate $1.75 \%$ with CaCl $100 \mathrm{mM})$. 
Citation: Rilianawati R, Ago H, Subintoro, Elrade R, Kurnia A (2018) Optimization of Alginate-Based Encapsulation Utilization For Viability and Stability of The Mesenchymal Stem Cell. J Stem Cell Res Ther 8: 412. doi: 10.4172/2157-7633.1000412

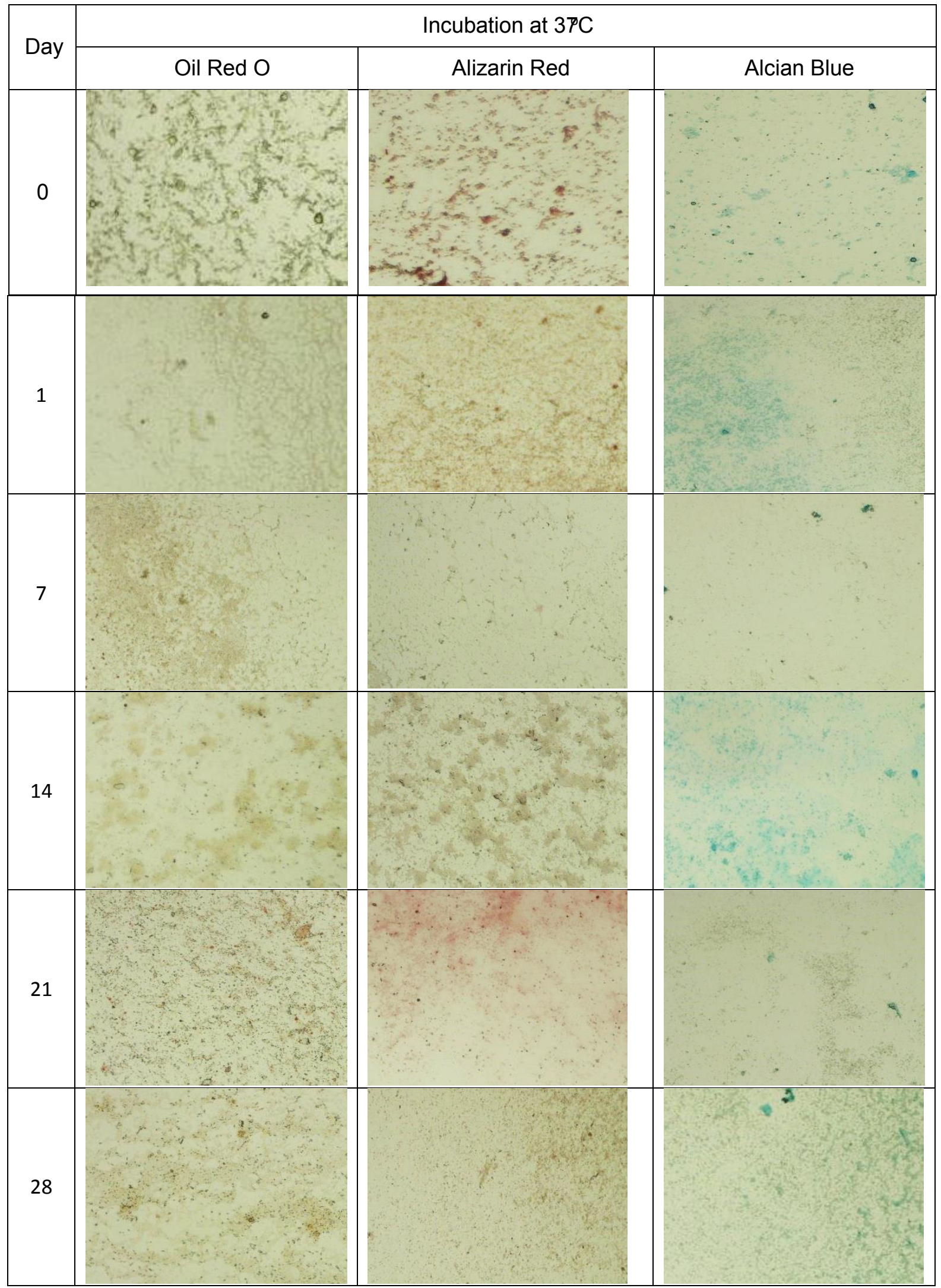

Table 4: Stability of MSCs (Alginate $1.75 \%$ with $\mathrm{CaCl}_{2} 100 \mathrm{mM}$ ) using Oil Red O, Alizarin Red and Alcian blue staining. 
Citation: Rilianawati R, Ago H, Subintoro, Elrade R, Kurnia A (2018) Optimization of Alginate-Based Encapsulation Utilization For Viability and Stability of The Mesenchymal Stem Cell. J Stem Cell Res Ther 8: 412. doi: 10.4172/2157-7633.1000412

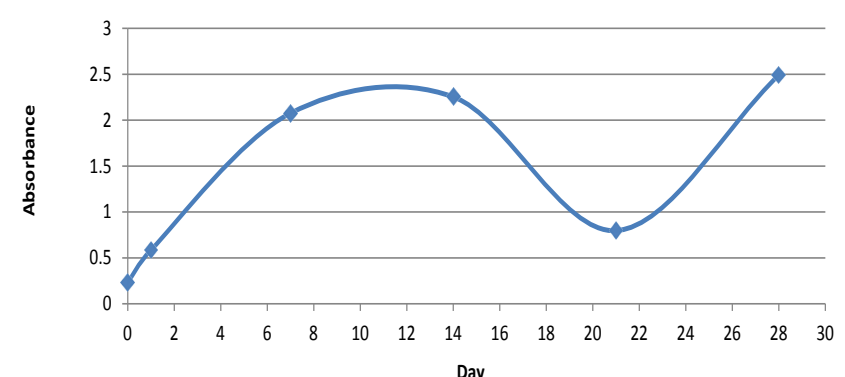

Figure 3: Absorbance value based on MTT assay of Alginate $1.5 \%$ with $\mathrm{CaCl}_{2}$ $100 \mathrm{mM}$ at $37^{\circ} \mathrm{C}$

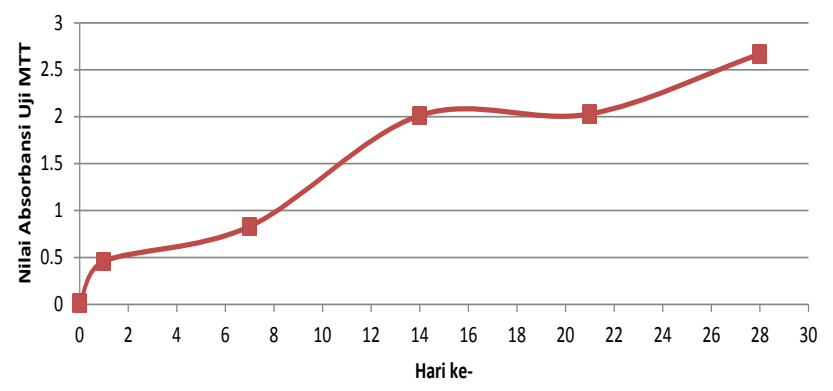

Figure 3a: Absorbance value based on MTT assay of Alginate $1.5 \%$ with $\mathrm{CaCl}_{2}$ $100 \mathrm{mM}$ at $25^{\circ} \mathrm{C}$

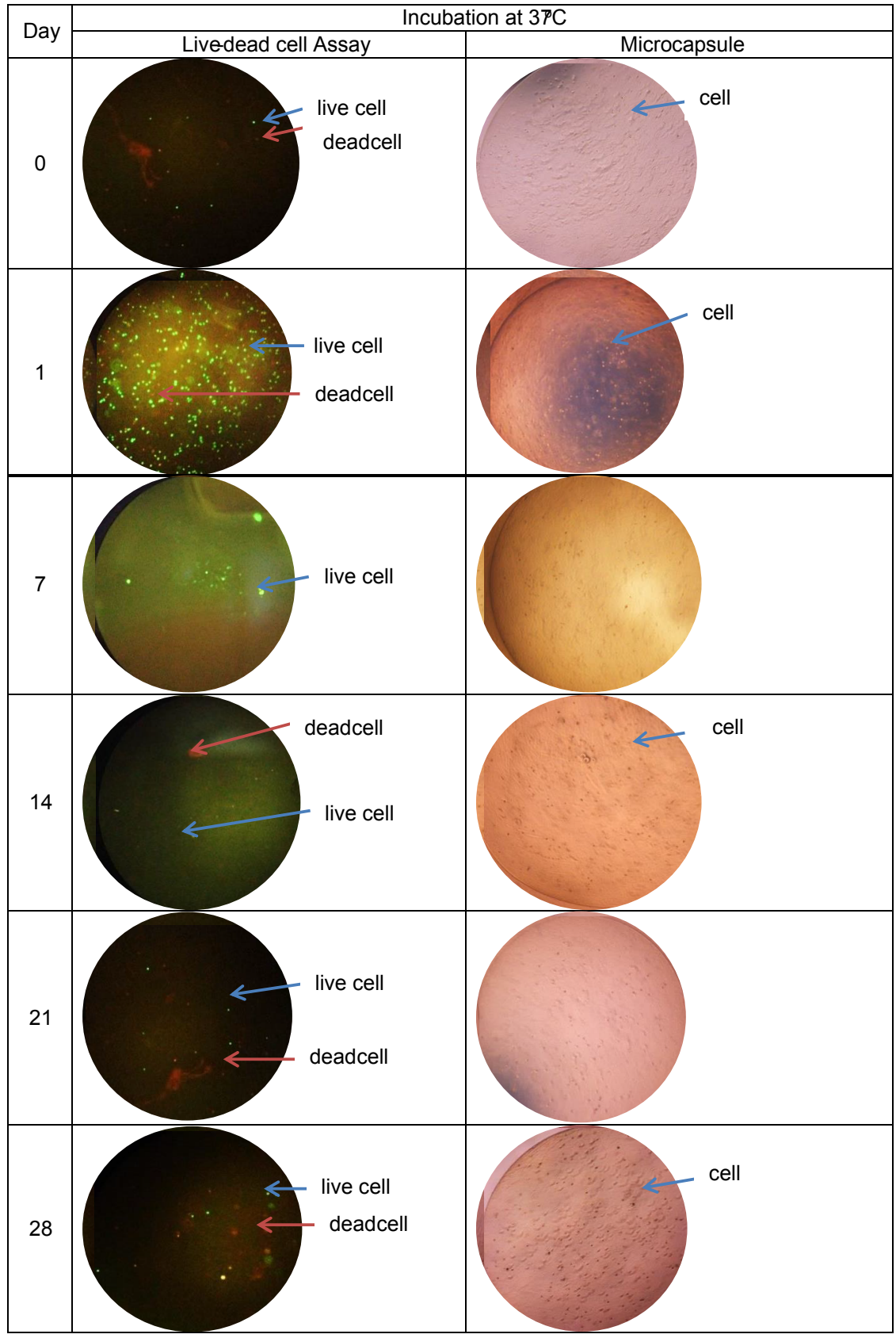

Table 5: Viability of MSCs after alginate encapsulated MSCs for day-0, day-1, day-7, day-14, day-21, and day-28 using Live-dead cell assay (Alginate 1.5\% with CaCl $100 \mathrm{mM})$. 
Citation: Rilianawati R, Ago H, Subintoro, Elrade R, Kurnia A (2018) Optimization of Alginate-Based Encapsulation Utilization For Viability and Stability of The Mesenchymal Stem Cell. J Stem Cell Res Ther 8: 412. doi: 10.4172/2157-7633.1000412

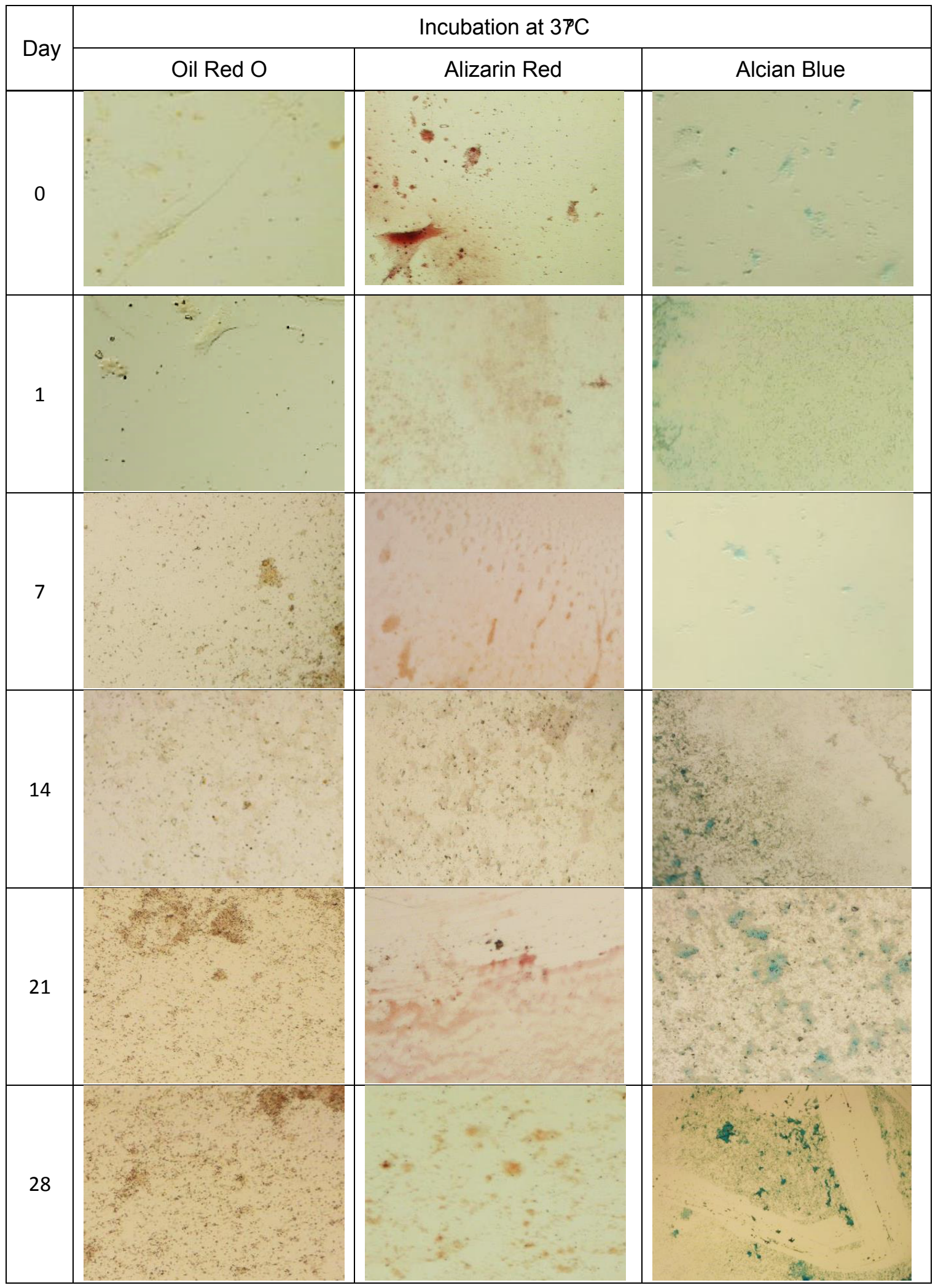

Table 6: Stability of MSCs (Alginat 1.5\% with $\mathrm{CaCl}_{2} 100 \mathrm{mM}$ ) using Oil Red O, Alizarin Red and Alcian blue staining 
Citation: Rilianawati R, Ago H, Subintoro, Elrade R, Kurnia A (2018) Optimization of Alginate-Based Encapsulation Utilization For Viability and Stability of The Mesenchymal Stem Cell. J Stem Cell Res Ther 8: 412. doi: 10.4172/2157-7633.1000412

Page 10 of 14

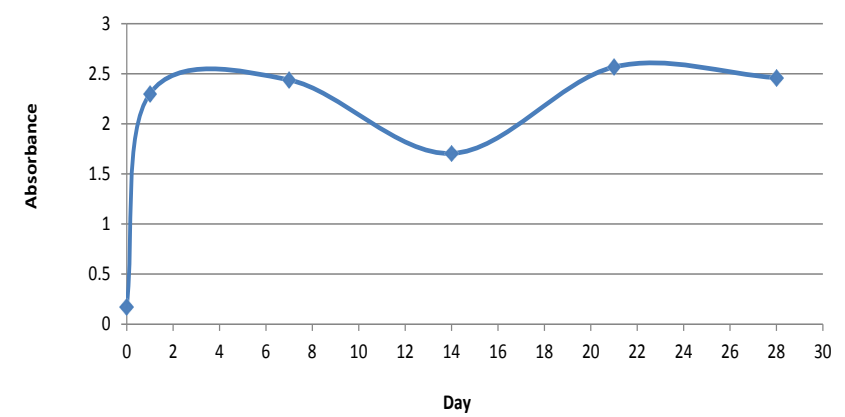

Figure 4: Absorbance value based on MTT assay of Alginate 1,25\% with $\mathrm{CaCl}_{2} 100 \mathrm{mM}$ at $37^{\circ} \mathrm{C}$.

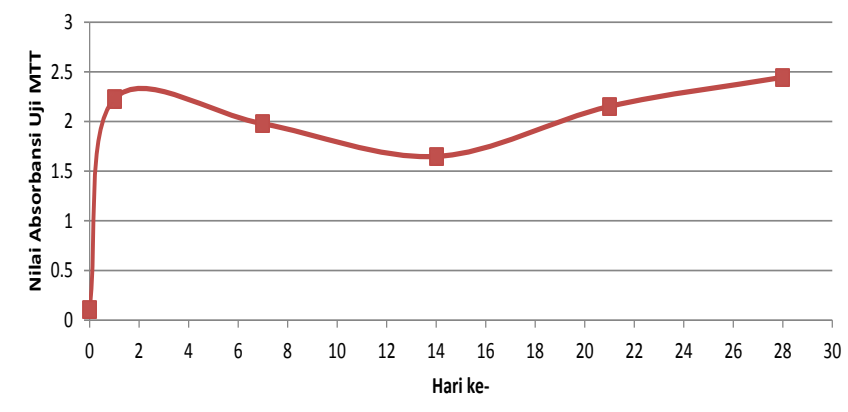

Figure 4a: Absorbance value based on MTT assay of Alginate $1.25 \%$ with $\mathrm{CaCl}_{2} 100 \mathrm{mM}$ at $25^{\circ} \mathrm{C}$

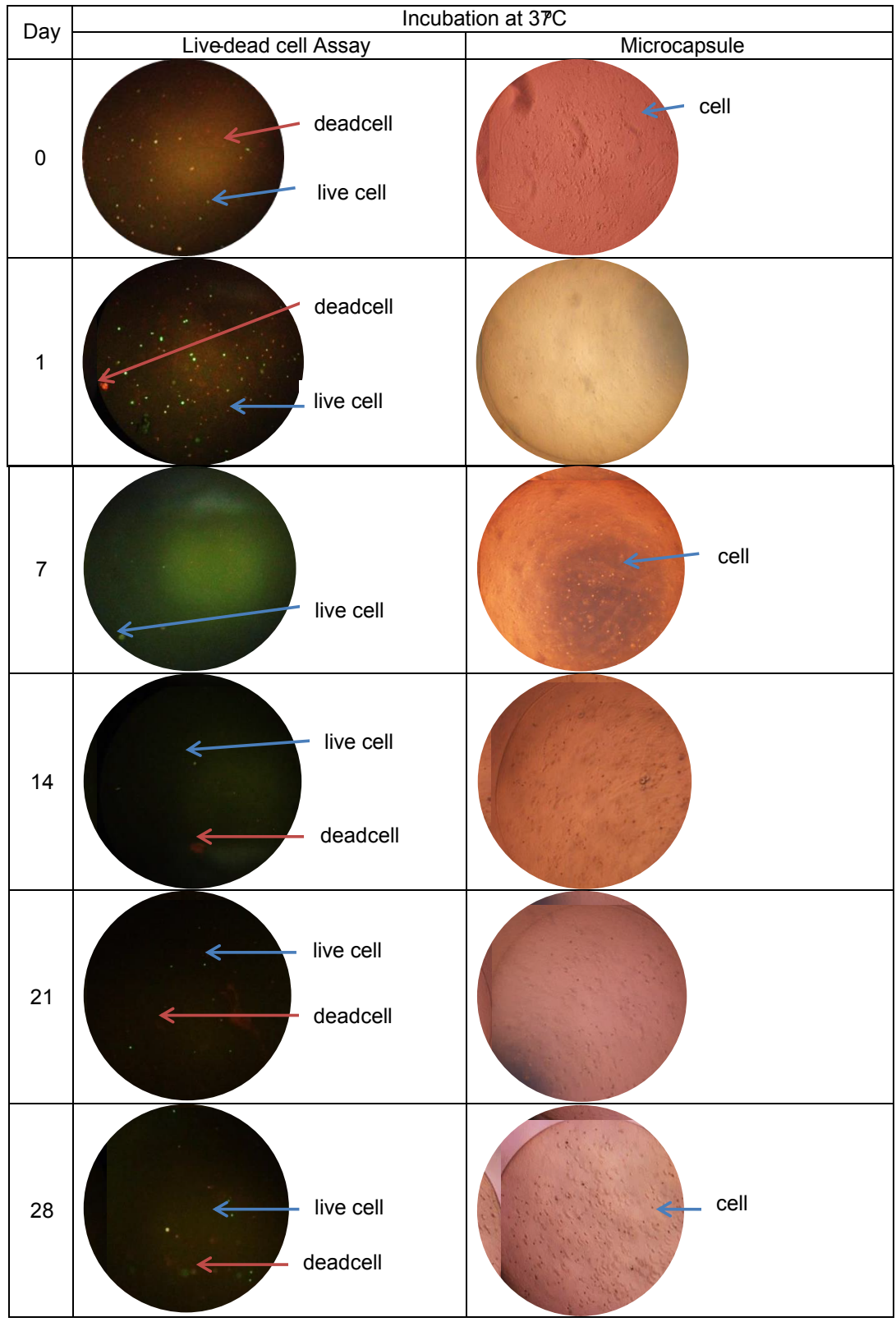

Figure 7: Viability of MSCs after alginate encapsulated MSCs for day-0, day-1, day-7, day-14, day-21, and day-28 using Live-dead cell assay (Alginate 1.25\% with CaCl $100 \mathrm{mM})$. 


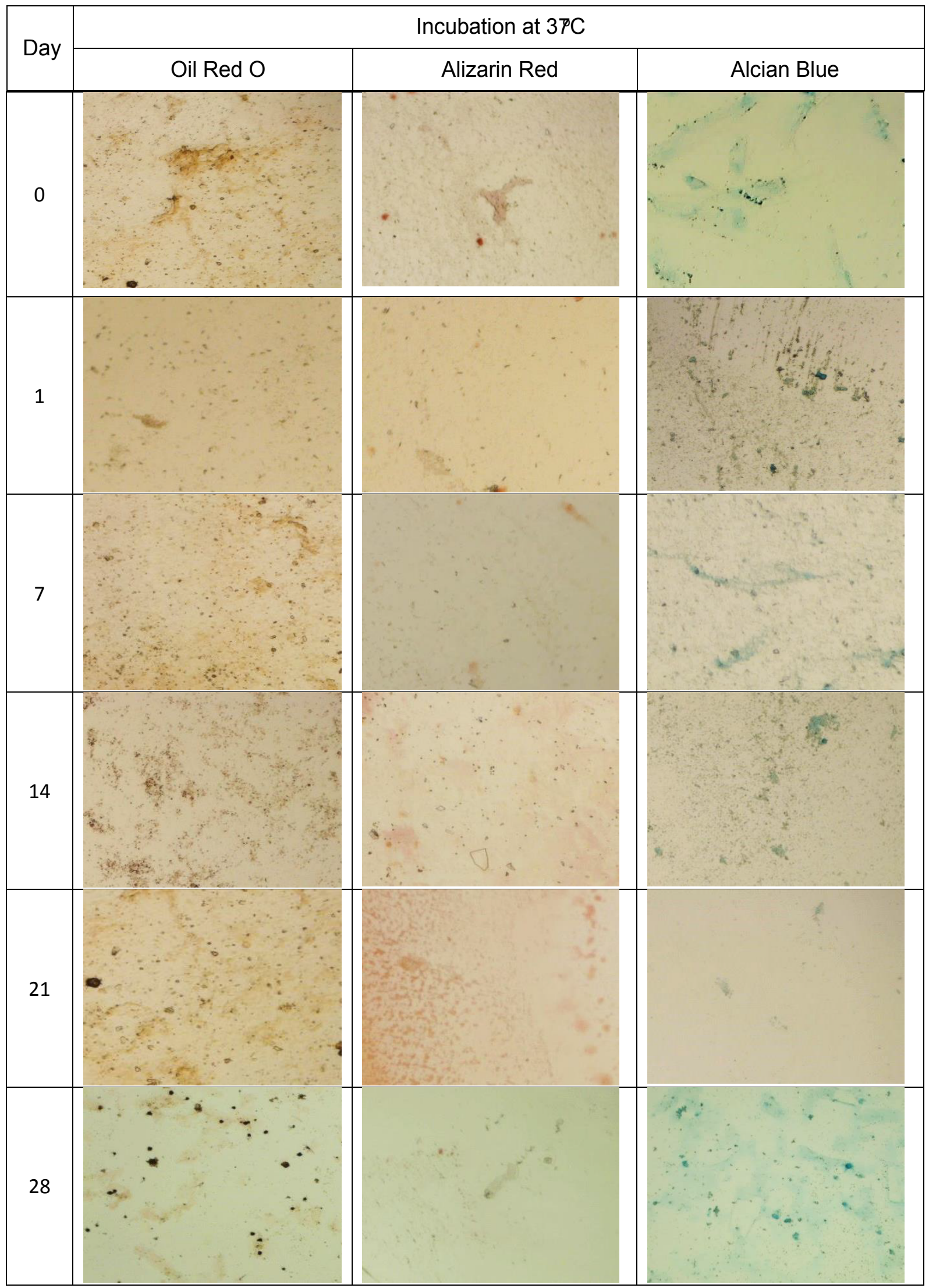

Table 8: Stability of MSCs (Alginate $1.25 \%$ with $\mathrm{CaCl}_{2} 100 \mathrm{mM}$ ) using Oil Red O, Alizarin Red and Alcian blue staining. 
Citation: Rilianawati R, Ago H, Subintoro, Elrade R, Kurnia A (2018) Optimization of Alginate-Based Encapsulation Utilization For Viability and Stability of The Mesenchymal Stem Cell. J Stem Cell Res Ther 8: 412. doi: 10.4172/2157-7633.1000412

Page 12 of 14

Live dead assay (LDA): Viability of MSCs after alginate encapsulated MSCs for day 0 , day 1 , day 7, day 14, day 21, and day 28 using Live-dead cell assay (Alginate $1 \%$ with $\mathrm{CaCl}_{2} 100 \mathrm{mM}$ ) (Table 9).

Stability assay: After a 28-day encapsulation in alginate microcapsules there was no differentiation of MSCs in microencapsulation (Table 10).

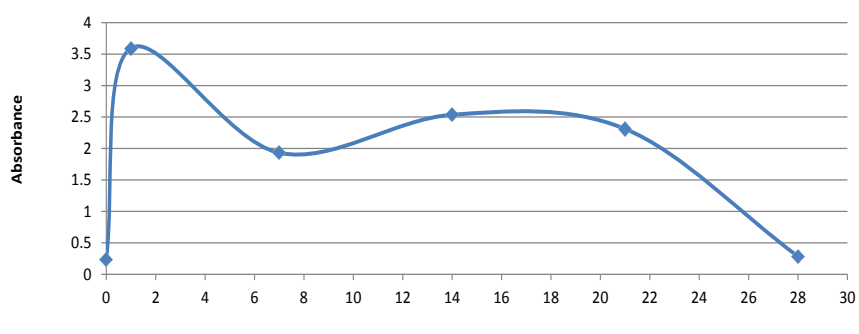

Day

Figure 5: Absorbance value based on MTT assay of Alginate $1 \%$ with $\mathrm{CaCl}_{2}$ $100 \mathrm{mM}$ at $37^{\circ} \mathrm{C}$

\section{Conclusion}

The viability of mesenchymal stem cells in alginate microcapsules can last up to 28 days and there is no differentiation into adipose, chondrocytes and osteoblasts. It can suggest that MSCs encapsulated can use for transport MSCs from one laboratory to other laboratory for more than 24 hours. And also because of condition in other laboratory/

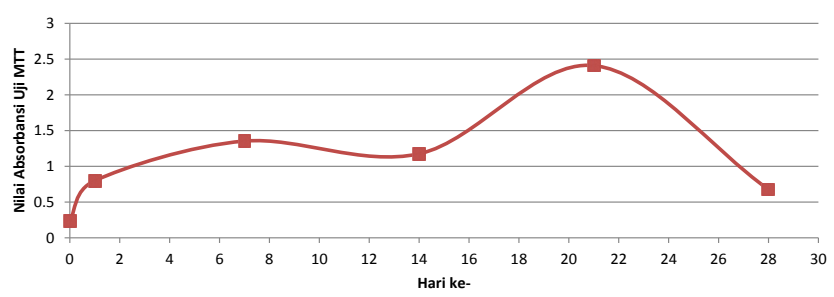

Figure 5a: Absorbance value based on MTT assay of Alginate $1 \%$ with $\mathrm{CaCl}_{2}$ $100 \mathrm{mM}$ at $25^{\circ} \mathrm{C}$.

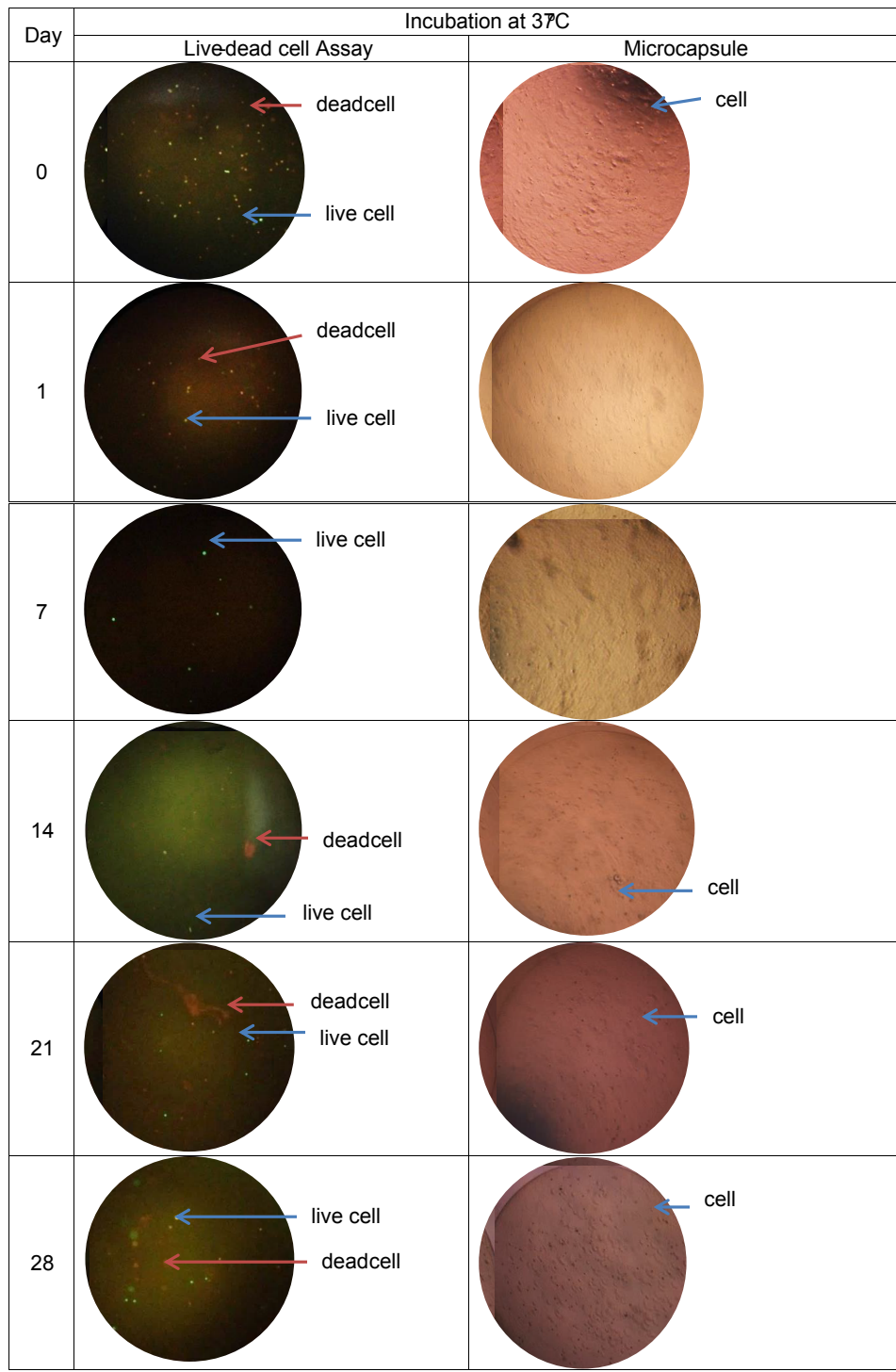

Table 9: Viability of MSCs after alginate encapsulated MSCs for day-0, day-1, day-7, day-14, day-21, and day-28 using Live-dead cell assay ( $\mathrm{Alginate}_{1} \%$ with $\mathrm{CaCl}, 100$ $\mathrm{mM})$. 
Citation: Rilianawati R, Ago H, Subintoro, Elrade R, Kurnia A (2018) Optimization of Alginate-Based Encapsulation Utilization For Viability and Stability of The Mesenchymal Stem Cell. J Stem Cell Res Ther 8: 412. doi: 10.4172/2157-7633.1000412

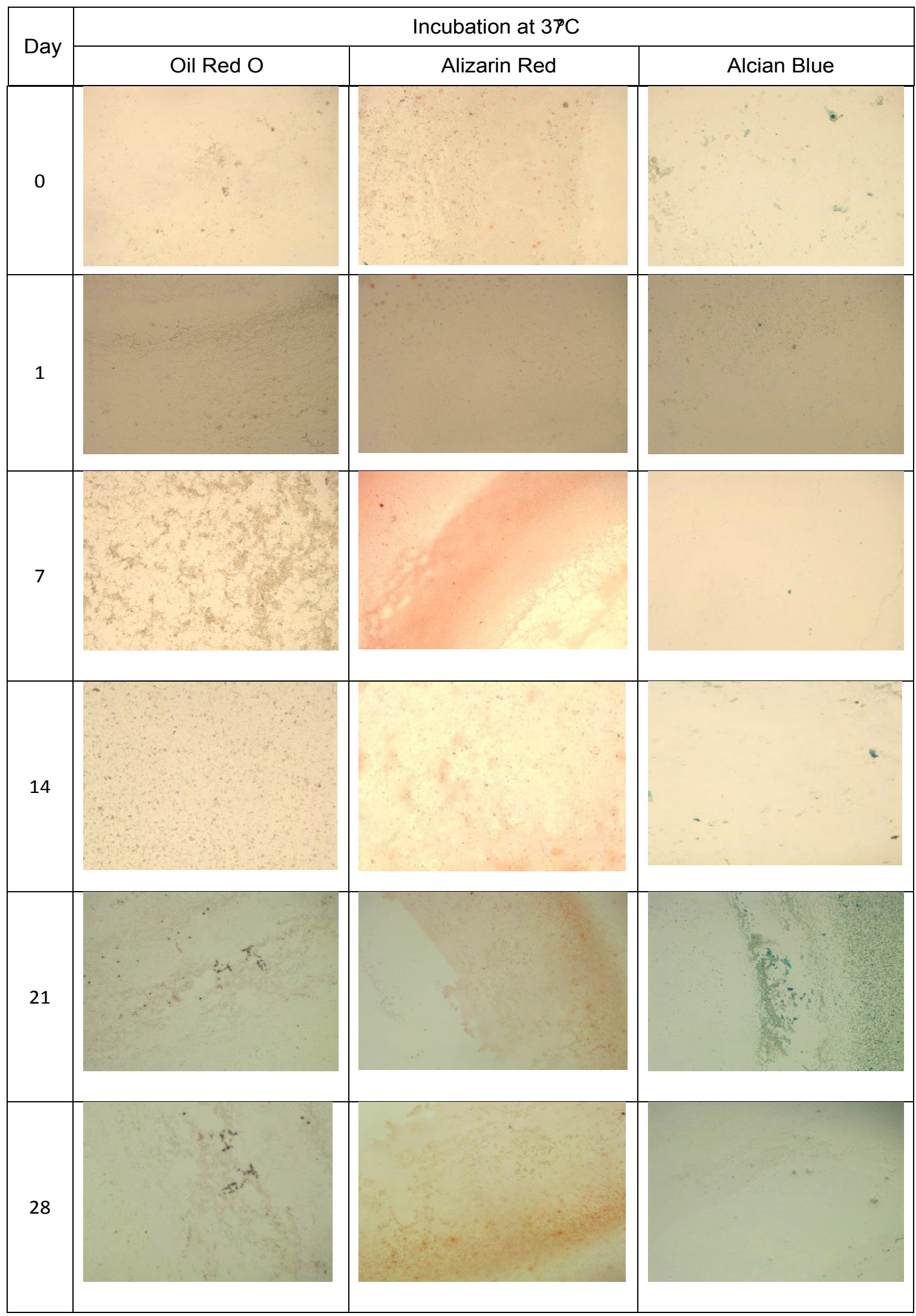

Table 10: Stability of MSCs (Alginate $1 \%$ with $\mathrm{CaCl}_{2} 100 \mathrm{mM}$ ) using Oil Red O, Alizarin Red and Alcian blue staining. 
Citation: Rilianawati R, Ago H, Subintoro, Elrade R, Kurnia A (2018) Optimization of Alginate-Based Encapsulation Utilization For Viability and Stability of The Mesenchymal Stem Cell. J Stem Cell Res Ther 8: 412. doi: 10.4172/2157-7633.1000412

clinic which will use MSCs not always have liquid nitrogen storage. This result also shows that alginat with low concentration and $\mathrm{CaCl}_{2}$ $100 \mathrm{mM}$ is good for MSCs growth (as in MTT result shown). This can be due to the MSCs encapsulated can adapt and grow within the alginate microcapsule with low concentration. In addition, the media may also easier to get into the microcapsule alginate. However these results need further investigations.

\section{References}

1. Siti-Ismail NB, Polak AE, Mantalaris JM (2008) The benefit of human embryonic stem cell encapsulation for prolonged feeder-free maintenance. Biomaterials 29: 3946-3962. [PubMed]

2. Swioklo S, Constantinescu A, Connon CJ (2016) Alginate-encapsulation for the improved hypothermic preservation of human adipose-derived stem cells. Stem Cell Trans Med 5: 339-349. [PubMed]

3. Witkowska-Zimny M, Dan-Walenko K (2011) Stem cells from adipose tissue. Cell Mol Bio Letters 16: 236-257. [PubMed]
4. Yang H, Dan-Wright R, Dalam KWM, Lanza RP, Chick WL (1999) Cell Encapsulation Technology and Therapeutics. Springer Science Business Media, LLC. New York.

5. Lee KY, Dan-Mooney DJ (2012) Alginate: properties and biomedical applications. Prog Polym Sci 37: 106-126. [PubMed]

6. Duscher D, Barrera J, Wong VW, Maan ZN, Whittam AJ, et al. (2016) Stem cells in wound healing: the future of regenerative medicine? A mini review. Gerontology 62: 216-225. [PubMed]

7. Chen PM, Yen ML, Liu KJ, Sytwu HK, Yen BL (2011) Immunomodulatory properties of human adult and fetal multipotent mesenchymal stem cells. $\mathrm{J}$ Biomed Sci. 18: 49. [PubMed]

8. Freshney RI (2010) Culture of Animal Cells: A Manual of Basic Technique and Specialized Applications. Six Edition. Cancer Research UK Centre for Oncology and Applied Pharmacology, Division of Cancer Sciences and Molekuler Pharmacology, University of Glasgow. Wiley-Blackwell, A John Wiley \& Sons, Inc., Publication.

9. Chen HH, Decot JP, Ouyang JF, Stoltz D, Bensoussan NG (2009) In Vitro initial expansion of Mesenchymal Stem Cells is influenced by the culture parameters used in the isolation process. Bio-Med Mat Eng 19: 301-309. [PubMed] 